\title{
PEMBELAJARAN STRATEGI PEMECAHAN MASALAH SISTEMATIS DAN WANKAT-OREOVOCZ BERBANTUAN METODE EKSPERIMEN DAN DEMONSTRASI UNTUK MENINGKATKAN HASIL BELAJAR KOGNITIF PESERTA DIDIK PADA MATERI OPTIK
}

\author{
Fian Irsada \\ SMK Modellink Kab. Sorong; fianirsada07@gmail.com
}

\begin{abstract}
The purpose of this study was to determine the interaction between the application of learning systematic problem solving solutions and Wanket-Oreovocz. Experimental and demonstration methods have different effects. The number of students in this study were 70 students who were divided into two classes, namely the application of systematic problem solving strategy learning which amounted to 34 students and the application of the Wanket-Oreovocz problem solving strategy class totaled 36 students in terms of the application of experiments and demonstrations. learning methods. Samples were taken using the purposive sampling technique. The research design used in this study is a factorial design. Data analysis using Anova technique with SPSS software version 16.0..

Research results of data analysis in this research used to improve students' cognitive learning outcomes in terms of application of learning systematic troubleshooting strategy and demonstration method obtained 0.59 which was in moderate "category", the application of Wanket-Oreovocz troubleshooting strategy and experimental methods obtained 0.56 which was in moderate "category". Wanket-Oreovocz troubleshooting strategy that obtained 0.61 was also obtanined 0.61. Results hypothesis showed that there is difference in cognitive learning outcomes between the application of learning systematic troubleshooting strategy and Wanket-Oreovcz (sig-value $0.854>0,05$ ); there are differences in cognitive learning outcomes between the application of experimental method and demonstration method (sig-value $0.035<0.05$ ); and there is no interaction between systematic troubleshooting strategy and Wanket-Oreovcz, which demonstration method was better used than experiment method.
\end{abstract}

Key Words: Systematic Problem Solving Strategies; Wanket-Oreovocz; Experimental Method; Demonstration Method.

\footnotetext{
ABSTRAK

Tujuan penelitian ini untuk mengetahui interaksi antara penerapan pembelajaran solusi pemecahan masalah sistematis dan Wanket-Oreovocz. Metode eksperimental dan demonstrasi memiliki efek yang tidak sama. Jumlah peserta didik dalam penelitian ini sebanyak 70 peserta didik yang terbagi dalam dua kelas, yaitu penerapan pembelajaran strategi pemecahan masalah sistematis yang berjumlah 34 peserta didik dan penerapan kelas strategi pemecahan masalah Wanket-Oreovocz berjumlah 36 peserta didik ditinjau dari penerapan eksperimen dan demonstrasi. metode pembelajaran. Sampel diambil dengan menggunakan teknik Purposive Sampling. Desain penelitian yang digunakan dalam penelitian ini adalah desain faktorial. Analisis data menggunakan teknik Anova dengan Software SPSS versi 16.0 .

Hasil penelitian analisis data dalam penelitian ini digunakan untuk meningkatkan hasil belajar kognitif peserta didik ditinjau dari penerapan pembelajaran strategi pemecahan masalah sistematis dan metode demonstrasi diperoleh 0,59 yang berada pada kategori sedang, penerapan strategi pemecahan masalah Wanket-Oreovocz dan metode eksperimen diperoleh 0,56 yang termasuk dalam "kategori" sedang. Strategi pemecahan masalah Wanket-Oreovocz yang memperoleh 0,61 juga diperoleh 0,61. Hasil hipotesis menunjukkan bahwa terdapat perbedaan hasil belajar kognitif antara penerapan pembelajaran
} 
strategi pemecahan masalah sistematis dan Wanket-Oreovcz (nilai sig 0,854> 0,05); Terdapat perbedaan hasil belajar kognitif antara penerapan metode eksperimen dan metode demonstrasi (nilai sig $0,035<0,05)$, dan tidak terdapat interaksi antara strategi pemecahan masalah sistematis dan Wanket-Oreovcz, dimana metode demonstrasi lebih baik digunakan daripada metode eksperimen.

Kata Kunci: Strategi Pemecahan Masalah Sistematis; Wanket-Oreovocz; Metode Eksperimen; Metode Demonstrasi.

\section{PENDAHULUAN}

Pendidikan di Indonesia saat ini telah berubah paradigma yang dulu berbasis kompetensi karena kurangnya efektivitas dilapangan dan pemunduran pendidikan di Indonesia yang tidak sejalan dengan harapan yang dicita-citakan, sehingga pemerintah mengimplementasikan Kurikulum 2013 sebagai titik terang pendidikan saat ini, dimana pendidikan tidak hanya dilihat dari hasil belajar tetapi dilihat dari proses pembelajaran yang berlangsung. Bukan hanya itu hasil pembelajaran tidak hanya dilihat dari penilain pengetahuan saja tetapi juga dua aspek lain yaitu sikap dan ketrampilan.

Hal ini sejalan dengan UndangUndang Nomor 20 Tahun 2003 (Permendikbud, 2016:1) tentang SISDIKNAS, Pasal 1 angka 1 menyatakan bahwa pendidikan adalah usaha sadar dan terencana untuk mewujudkan suasana belajar dan proses pembelajaran agar peserta didik secara aktif mengembangkan potensi dirinya untuk memiliki kekuatan spiritual keagamaan, pengendalian diri, kepribadian, kecerdasan, akhlak mulia, serta keterampilan yang diperlukan dirinya, masyarakat, bangsa dan negara. Ini berlaku juga pada peraturan pemerintah, sehingga peserta didik baik dalam jejang pendidikan maupun lulusan memiliki kemampuan yang mencakup sikap, pengetahuan dan ketrampilan. Ini sesuai dengan PERMENDIKBUD Nomor 23 Tahun 2016 tentang Standar Penilaian Pendidikan Bab I pasal 1 point 6 dan Bab II pasal 3 point 1 .

Hasil observasi terhadap peserta didik SMP Negeri 11 Jayapura kelas VIII, menyatakan belajar Ilmu Pengetahuan Alam (IPA) khusus bidang fisika sangat sulit untuk dipelajari karena memerlukan penalaran yang baik ketika peserta didik dihadapkan suatu masalah yang berkaitan dengan gejala IPA, ketika ada perhitungan matematik kadang peserta didik sukar untuk mengoperasikan suatu bilangan ataupun mengkonversi suatu satuan besaran. Perlunya suatu penerapam strategi mengajar guna dapat mengatasi permasalahan yang dihadapi guru dalam pengajaran materi yang membutuhkan kemampuan berpikir kritis peserta didik, meski begitu peserta didik juga dapat menyesuaikan teknik belajar pada materi pembelajaran tertentu agar dapat menguasai secara utuh bukan hanya 
Jurnal Ilmu Pendidikan Indonesia 9 (2) : 68- $78 \mid 70$

konsep materi tetapi kemampuan menerapkan konsep tersebut dalam memecahkan suatu permasalahan.

Penerapan metode pembelajaran di kelas juga kurang diselingi dengan metodemetode pembelajaran yang lain. Salah satu metode pembelajaran yang paling sering digunakan guru dalam pengajaran adalah metode pembelajaran ceramah sehingga kegiatan belajar mengajar nampak monoton sehingga keaktifan belajar peserta didik cenderung rendah, ini juga akan mempengaruhi kemampuan kognitif, kemampuan psikomotor dan kemampuan afektif, sehingga kemungkinan yang mengakibatkan hasil belajar peserta didik rendah salah satunya adalah kurangnya penggunaan metode pembelajaran.

Berdasarkan data semester nilai ulangan kelas VIII untuk semua kelas ratarata mendapatkan nilai 39,03. Ini menandakan bahwa peserta didik mendapatkan nilai dibawah kriteria ketuntasan minimal (KKM) yaitu dibawah nilai 71. Banyak faktor yang mempengaruhi hasil belajar peserta didik tetapi jika dikaji lebih lanjut peserta didik kurang mampu menganalisis dan memecahkan masalah yang lebih kompleks. Menurut Bloom dalam (Supardi, 2015:2) salah satu dari tiga adalah tipe keberhasilan belajar kognitif meliputi pengetahuan, pemahaman, penerapan, analisis, sintesis dan evaluasi. Peserta didik cenderung kurang mampu menguasai 6 tahapan ini karena kurang dikembangkan teknik berpikir peserta didik, kadang kala peserta didik tidak mampu menyelesaikan masalah pada tahap-tahap akhir ranah kognitif. Kementrian Pendidikan dan Kebudayaan menyatakan ranah kognitif dalam sekolah menengah pertama telah dibatasi. dari pengetahuan, pemahaman dan sintesis karena dipengaruhi dari segi bertumbuhan peserta didik pada usia perkembangannya.

Strategi pemecahan yang menjadi solusi antara lain yaitu strategi pemecahan masalah yang efektif yaitu pertama strategi pemecahan masalah sistematis (systematic to problem solving) menurut Kramers (Wena, 2014:60) merupakan petunjuk untuk melakukan suatu tindakan yang berfungsi untuk membantu seseorang dalam menyelesaikan suatu permasalahan. Kedua yang diperkenalkan oleh Wankat dan Oreovocz dalam (Wena, 2014:53) pembelajaran berbasis masalah merupakan strategi pembelajaran yang melibatkan peserta didik, peserta didik diajak untuk melihat proses pemecahan masalah yang kompleks. Pemetaan masalah yang dihadapi sangat perlu karena proses pemecahan masalah melibatkan proses berbagai aktivitas kognitif. Paparan pembelajaran berbasis masalah ini tentu peserta didik tidak belajar secara pasif lagi yang hanya menerima materi dari guru saja, tetapi peserta didik diminta aktif dalam belajar karena peserta didik 
diberikan permasalahan yang nanti akan diberi jalan keluarnya.

Pembelajaran yang mengajak peserta didik dalam memecahkan masalah ini juga bisa mengembangkan ketrampilan berpikir kritis peserta didik dan bisa menghadapi berbagai bentuk masalah dalam kehidupan nyata. Seperti dalam pernyataan (Komalasari, 2013:58) strategi pembelajaran menggunakan masalah dunia nyata sebagai suatu konteks bagi peserta didik untuk belajar berpikir kritis dan ketrampilan pemecahan masalah, serta untuk memperoleh pengetahuan dan konsep yang esensi dari mata pelajaran.

Berdasarkan permasalahan yang didapat di lapangan maka dilakukan penelitian penerapan strategi pembelajaran pemecahan masalah sistematis dan strategi pemecahan masalah Wankat-Oreovocz dengan berbantuan metode pembelajaran eksperimen dan metode pembelajaran demonstrasi untuk meningkatkan hasil belajar kognitif peserta didik pada materi optik di kelas VIII SMP Negeri 11 Jayapura.

\section{METODE PENELITIAN}

Penelitian ini merupakan penelitian kuantitatif eksperimen dengan metode ANOVA dua jalan dengan desain faktorial ordo $2 \times 2$ yang terdiri dari dua variabel variabel bebas pertama yang digunakan yakni variabel strategi pemecahan masalah yang terdiri dari dua kategori yaitu kategori ke satu strategi pemecahan masalah sistematis $\left(A_{1}\right)$ dan kategori ke dua startegi pemecahan masalah WankatOreovocz $\left(\mathrm{A}_{2}\right)$. Variabel bebas ke dua yaitu metode pembelajaran dengan dua kategori yaitu kategori satu metode pembelajaran eksperimen $\left(\mathrm{B}_{1}\right)$ dan kategori kedua metode pembelajaran demonstrasi $\left(B_{2}\right)$. Berdasarkan variabel tersebut diperoleh 4 sampel data penelitian independent. Desain penelitian $\mathrm{k}$ sampel independentANOVA dua jalan dengan desain faktorial ordo $2 \times 2$ dapat dilihat pada tabel 3.1.

Penelitian ini dilakukan di kelas VIII di SMP Negeri 11 Jayapura. Desain penelitian ditunjukkan pada tabel sebagai berikut:

Tabel: 1 Desain Penelitian

\begin{tabular}{|c|c|c|}
\hline Strategi & $\begin{array}{c}\text { Strategi } \\
\text { pemecahan } \\
\text { masalah } \\
\text { sistematis } \\
\left(\mathrm{A}_{1}\right)\end{array}$ & $\begin{array}{c}\text { Startegi } \\
\text { pemecahan } \\
\text { masalah } \\
\text { Wankat- } \\
\text { Oreovocz }\left(\mathrm{A}_{2}\right)\end{array}$ \\
\hline $\begin{array}{c}\text { Metode } \\
\text { Eksperimen }\left(\mathrm{B}_{1}\right)\end{array}$ & $\left(\mathrm{A}_{1}, \mathrm{~B}_{1}\right)$ & $\left(\mathrm{A}_{2}, \mathrm{~B}_{1}\right)$ \\
\hline $\begin{array}{c}\text { Metode } \\
\text { Demonstrasi } \\
\left(\mathrm{B}_{2}\right)\end{array}$ & $\left(\mathrm{A}_{1}, \mathrm{~B}_{2}\right)$ & $\left(\mathrm{A}_{2}, \mathrm{~B}_{2}\right)$ \\
\hline
\end{tabular}

Populasi dalam penelitian ini adalah peserta didik kelas VIII SMP Negeri 11 Jayapura. Sampel yang diambil adalah 2 kelas yang mewakili dari kelas VIII dengan kriteria yang sama (homogen), tidak adanya kelas unggulan. Pengambilan sampel menggunakan teknik sampling purposive dikarena berdasarkan asumsi dan pertimbangan peneliti untuk 
Jurnal Ilmu Pendidikan Indonesia 9 (2) : 68- $78 \mid 72$

mempermudahkan penelitian dan ini juga didukung dari kerja sama terhadap salah satu guru mata pelajaran IPA yang memegang tiga kelas untuk kelas VIII, maka digunakan dua kelas dari tiga kelas yang ada, tiga kelas ini terdiri dari kelas VIIIA, kelas VIIIB dan kelas VIIIC. Berdasarkan data nilai harian IPA dari ketiga kelas didapatkan masing-masing kelas dengan nilai rata-rata; 36,89; 37,38 dan 42,81 .

Berdasarkan pertimbangan Peneliti maka dipilih kelas VIIIA dan VIIIB sebagai kelas sampel, karena kemampuan kognitif dari hasil Nilai harian di kedua kelas memiliki nilai rata-rata yang tidak jauh berbeda. Pelaksanaan dilapangan kelas VIIIA akan diterapkan strategi pemecahan masalah sistematis dan kelas VIIIB akan diterapkan strategi pemecahan masalah Wankat-Oreovocz.

Pengambilan data hasil belajar kognitif peserta didik menggunakan tes pilihan ganda dengan 4 pilihan jawaban dengan tes jumlah tes sebanyak dua soal. Soal pertama untuk mengukur hasil belajar kognitif peserta didik strategi pemecahan masalah sistematis dengan metode eksperimen, dan strategi pemecahan masalah Wankat-Oreovocz dengan metode eksperimen. soal kedua untuk mengukur hasil belajar kognitif peserta didik strategi pemecahan masalah sistematis dengan metode demonstrasi, dan strategi pemecahan masalah Wankat-Oreovocz dengan metode demonstrasi.

\section{HASIL DAN PEMBAHASAN}

Berdasarkan data yang diperoleh dalam penelitian penerapan strategi pemecahan masalah sistematis dan strategi pemecahan masalah Wankat-Oreovocz dengan keduanya menggunakan berbantuan metode demonstrasi rata-rata $n$ Gain dijabarkan pada Gambar 1 berikut.

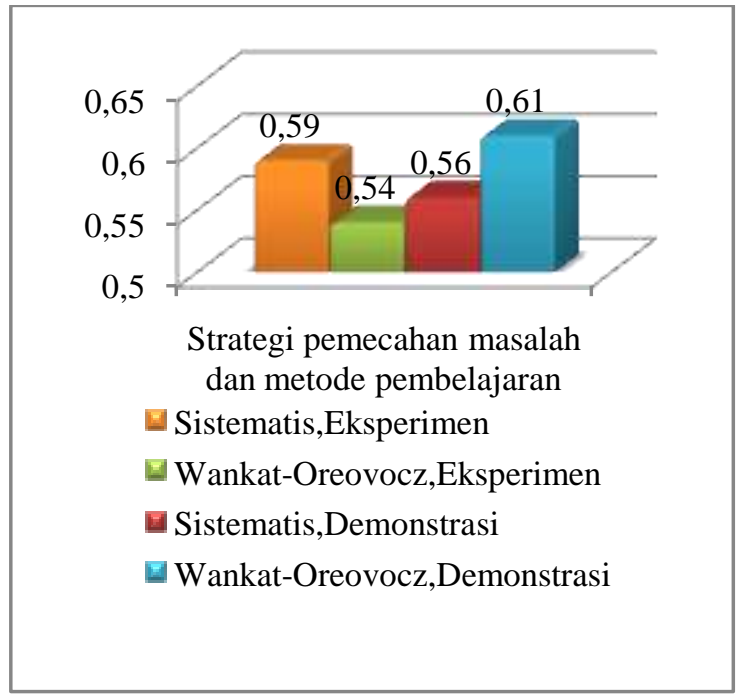

Gambar1: n-Gain rata-rata hasil belajar berbagai metode

Berdasarkan hasil pengolahan data didapat nilai sig. strategi pemecahan masalah 0,854 lebih besar dari 0,05 sehingga keputusan adalah terima $\mathrm{H}_{0}$. Hal ini bahwa tidak terdapat perbedaan signifikan hasil belajar kognitif peserta didik penerapan strategi pemecahan masalah sistematis dan penerapan strategi pemecahan masalah WankatOreovocz.Hasil penelitian ini menyatakan tidak ada perbedaan hasil belajar kognitif 
peserta didik antara pengajaran dengan strategi pemecahan masalah sistematis dan strategi pemecahan masalah WankatOreovocz. Berdasarkan hasil penelitian hasil belajar kognitif pada penerapan strategi pemecahan masalah sistematis sebesar 64,78 dan hasil belajar kognitif pada penerapan strategi pemecahan masalah Wankat-Oreovocz sebesar 64,32. Kedua strategi pemecahan masalah ini tidak mempengaruhi hasil belajar kognitif peserta didik, dari permasalahan yang diberikan masih didapatkan kendalakendala dan kesulitan untuk dipecahkan peserta didik sehingga perlu kerja sama yang baik dengan teman kelompok serta bimbingan dari guru. Ini sejalan dengan penelitian (Linuhung, Pengaruh Strategi Pemecahan Masalah Wankat-Oreovocz dan Pembelajaran Probing Terhadap Kemampuan Literasi Matematis Peserta didik SMP, 2014:40) yang menyatakan peningkatan strategi pemecahan masalah dengan PAM di bawah 0,7. Hasil penelitian ini juga senada dalam penelitian (Setiawan, 2008:49) bahwa penyelesaian masalah dengan persamaan matematis maupun alternatif-alternatif jawaban jika tidak menggunakan perhitungan tidak langsung diberikan jawaban tersebut tetapi dibahas secara bersama dengan cara itu peserta didik akhirnya selalu berpikir untuk memecahkan masalah atau mencari jawaban atas yang sedang dihadapi. Hasil penelitian ini juga sejalan dengan penelitian (Ernawati, Suharto, \& Kristina, 2015:206) bahwa strategi pemecahan masalah Wankat-Oreovocz peserta didik diharapkan memiliki motivasi untuk bisa menyelesaikan masalah yang diberikan, guru sangat berperan penting pada setiap tahap dan khususnya membimbing perencanaan dan penyelesaikan masalah yang dihadapi, sebagian peserta didik belum mampu menyelesaikan dengan permasalah menggunakan strategi pemecahan sistematis, dikarenakan peserta didik tidak mengikuti intruksi dari guru.

Strategi pemecahan masalah dalam penerapannya peserta didik kurang mampu untuk menyelesaikan masalah yang sedang dihadapi masih perlunya bantuan bimbingan guru secara menyeluruh untuk menyelesaikkannya. Berdasarkan analisis data dan pembahasan maka dapat dinyatakan bahwa strategi pemecahan masalah sistematis maupun WankatOreovocz belum dapat meningkatkan hasil belajar kognitif peserta didik khususnya pada mata pelajaran IPA di kelas VIII.

Hasil pengolahan data didapat nilai sig. metode pembelajaran adalah 0,035 lebih kecil dari 0,05 sehingga keputusan adalah terima $\mathrm{H}_{\mathrm{a}}$. Hal ini berarti terdapat perbedaan signifikan hasil belajar kognitif peserta didik dari penerapan metode pembelajaran antara metode eksperimen dan metode demonstrasi. Berdasarkan hasil uji statistik menerima $\mathrm{Ha}$ yaitu terdapat perbedaan hasil belajar kognitif peserta 
Jurnal Ilmu Pendidikan Indonesia 9 (2) : 68- $78 \mid 74$

didik yang diajarkan dengan metode eksperimen dan metode demonstrasi ditinjau dari penerapan strategi pemecahan masalah sistematis dan Wankat-Oreovocz. Bisa dilihat dari hasil belajar kognitif peserta didik pada penerapan metode eksperimen sebesar 61,94 sedangkan pada penerapan metode demonstrasi sebesar 67,16; Peserta didik yang diajarkan dengan metode eksperimen mendapatkan lebih rendah dari peserta didik yang diajarkan dengan metode demonstrasi dari hasil belajar kognitifnya. Berdasarkan analisis data maka dapat disimpulkan bahwa metode pembelajaran demonstrasi lebih baik dari metode eksperimen.

Berdasarkan hasil kognitif belajar peserta didik dengan metode eksperimen mendapatkan nilai rata-rata sebesar 61,99 dan masih di bawah KKM 71. Secara garis besar metode eksperimen adalah peserta didik melakukan percobaan dengan mengalami dan membuktikan sendiri yang dipelajari, metode eksperimen ini setelah guru menerangkan materi pokok secara klasikal dan pemberian LKS yang berisi suatu percobaan dan latihan soal. Peserta didik sebagian kecil melaksanakan percobaan cenderung kurang fokus pada bahasan yang sedang dilakukan, sehingga ada yang memainkan alat percobaan. Hasil penelitian ini sejalan dengan penelitian (Hartono \& Pratiwi, 2014:37) bahwa pembelajaran menggunakan metode eksperimen lebih rendah dari pada pembelajaran secara klasikal dalam kriteria keaktifan belajar. Hasil penelitian ini juga senada dengan penelitian (Mulyani, 2015:52) menyatakan bahwa peserta didik yang diajarkan dengan metode eksperimen salah satunya disebabkan kemampuan mengingat dan berpikir beberapa peserta didik sangat rendah sehingga evaluasi belajar peserta didik tidak memuaskan. Berdasarkan analisis data dan uraian sebelumnya sehingga metode eksperimen dapat meningkatkan belajar bila disesuaikan dengan kemampuan peserta didik, materi ajar dan bahan percobaan agar tujuan pembalajaran bisa tercapai.

Hasil pengolahan data, nilai sig. 0,313 lebih besar dari 0,05 sehingga keputusannya adalah terima $\mathrm{H}_{0}$, berarti bahwa tidak ada interaksi antara strategi pemecahan masalah dengan metode pembelajaran. Hasil penelitian ini dan pengolahan data didapat bahwa tidak terdapat interaksi antara penerapan strategi pemecahan masalah dan penerapan metode pembelajaran terhadap hasil belajar kognitif peserta didik pada materi optik di kelas VII SMP Negeri 11 Jayapura, strategi pemecahan yang terdiri dari strategi pemecahan masalah sistematis dan strategi pemecahan masalah Wankat-Oreovocz. Metode pembelajaran yang terdiri dari metode pembelajaran eksperimen dan metode demonstrasi nampak pada gambar 2. 


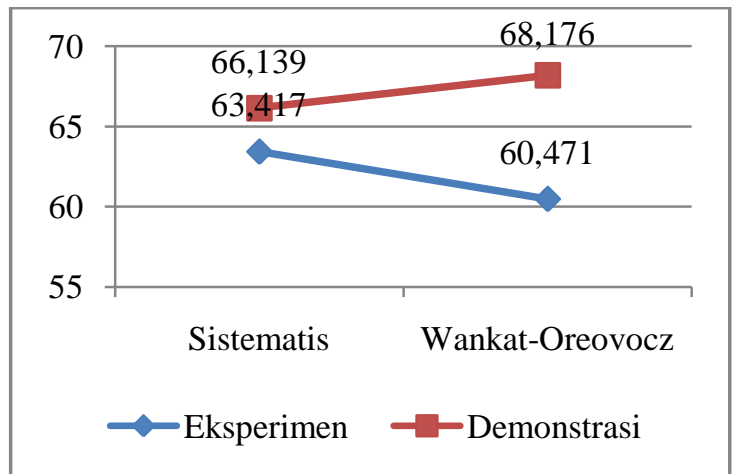

Gambar 2. Pola interaksi hasil belajar kognitif antara faktor strategi pemecahan masalah dengan metode pembelajaran

Rata-rata hasil belajar kognitif peserta didik ternyata metode demonstrasi selalu lebih baik dari metode eksperimen, baik menggunakan strategi pemecahan masalah sistematis maupun WankatOreovocz pada materi optik. Ini dikarenakan dalam pembelajaran peserta didik lebih terfokus pada penjelasan materi yang lebih jelas dan detail memungkin peserta didik lebih mudah menerima pelajaran dari pada metode eksperimen dimana khususnya peserta didik SMP kesulitan untuk menemukan dan menggunakan pemahaman yang didapat untuk memecahkan masalah.

Hasil penelitian sejalan dengan penelitian (Dahyana, 2014:132) yang menyimpulkan bahwa metode demonstrasi sebagai metode pembelajaran yang menekankan pergerakan secara langsung materi sehingga dapat meningkatkan kualitas proses pembelajaran IPA terpadu. Melalui penerapan metode demonstrasi yang melibatkan peserta didik dalam pembelajaran dengan cara memperagakan secara langsung materi, peserta didik dapat lebih mudah memahami materi pelajaran sehingga dapat meningkatkan kemampuan belajar serta hasil belajar peserta didik. Hasil penelitian ini juga sejalan dengan penelitian (Subrata, 2016:43) yang menyimpulkan bahwa 1) Pembelajaran IPA dengan metode demonstrasi dapat meningkatkan aktivitas peserta didik dalam pembelajaran, 2) Dengan peningkatan aktivitas peserta didik dalam hasil hasil belajar. Jika dihubungkan dengan garis hubung rata-rata kognitif peserta didik pada demonstrasi strategi pemecahan masalah Wankat-Oreovocz lebih tinggi dari sistematis. Hasil penelitian ini sejalan dengan penelitian (Subrata, 2016:43) menyatakan bahwa penerapan metode demonstrasi dalam pembelajaran IPA dapat meningkatkan aktivitas peserta didik dalam pembelajaran dan ada peningkatan aktivitas peserta didik dalam pembelajaran dapat meningkatkan hasil belajar peserta didik.

Hasil penelitian ini juga diperkuat oleh penelitian (Ernawati, Suharto, \& Kristina, 2015:209) menyimpulkan bahwa penerapan strategi pemecahan masalah berdasarkan teori Wankat-Oreovocz pada pokok bahasan sistem persamaan dan pertidaksamaan linear satu variabel masih harus dioptimalkan, namun secara umum mudah berjalan dengan semestinya. Misalkan soal yang terlalu sulit bagi peserta didik sehingga mereka masih 
bingung dalam mengerjakan soal. Disini butuh kerja ekstra dari guru. Mengeksplorasi peserta didik kadang perlu lama untuk membuat mereka mengajukan pertanyaan dan aktif dalam pembelajaran serta mampu berpikir kritis. Namun kendala seperti ini masih bisa teratasi pada pertemuan selanjutnya. Ada juga peserta didik yang mengalami kesulitan dalam tahapan mengerjakan karena kebanyakan dari mereka kurang menguasai dalam perhitungan. Kelebihan dari penerapan strategi ini adalah bimbingan yang harus tetap intens karena mereka bisa paham pembelajaran terletak dari guru yang membimbing dan menjelaskan.

Berdasarkan gambar 2 hasil belajar kognitif peserta didik dengan pembelajaran metode demonstrasi dan strategi pemecahan masalah sistematis sebesar 66,139 lebih rendah dari pada penerapan metode eksperimen dengan strategi pemecahan masalah Wankat-Oreovocz sebesar 68,176. Pada metode eksperimen dengan strategi pemecahan masalah sistematis sebesar 63,417 lebih tinggi dari pada penerapan metode eksperimen dengan startegi pemecahan masalah Wankat-Oreovocz. Ini dikarenakan metode eksperimen diperlukan keterampilan peserta didik dalam melakukan kerja dan diperlukan waktu belajar yang lebih ditambah peserta didik untuk menyelesaikan masalah.
Hasil penelitian ini diperkuat oleh hasil penelitian (Kholifudin, 2012:149) yang menyatakan bahwa metode eksperimen peserta didik dihadapkan langsung pada obyek, mengakomodasikan peserta didik bertipe gaya belajar kinestetik, menuntut kejelian dan ketelitian dalam pengamatan serta pengambilan datadata percobaan. Sedangkan jika ditinjau pemecahan masalah sistematis lebih mudah tahapannya dari Wankat-Oreovocz dalam menyelesaikan sebuah masalah karena sudah diberikan arah yang terstruktur dan detail. Hasil penelitian ini juga sejalan dengan penelitian (Hartono \& Pratiwi, 2014:38) yang menyatakan bahwa penerapan metode eksperimen memiliki kelemahan-kelemahan pada pembelajaran antara lain : 1) Beberapa peserta didik masih acuh tak acuh dalam melakukan eksperimen banyak yang bermain dan mengobrol sesama teman; 2) Guru kurang membimbing kelompok secara menyeluruh dalam proses pembelajaran eksperimen; 3) Guru kurang memotivasi dan penguatan kepada peserta didik untuk saling berdikusi dan bekerja sama.

Hasil analisis dapat disimpulkan tidak terdapat interaksi antara penerapan startegi pemecahan masalah dengan metode pembelajaran. Melalui penerapan strategi metode pembelajaran demonstarsi selalu lebih baik dari metode pembelajaran eksperimen pada materi optik. Penerapan strategi pemecahan masalah sistematis 
tidak terdapat perbedaan signifikan dengan startegi pemecahan masalah WankatOreovocz, baik menggunakan metode pembelajaran eksperimen dan metode pembelajaran demonstrasi. Penerapan metode demonstrasi selalu lebih baik dari metode pembelajaran eksperimen pada materi optik kelas VIII SMP Negeri 11 Jayapura.

\section{SIMPULAN}

Strategi pemecahan masalah sistematis Wankat-Oreovocz dengan metode pembelajaran terhadap hasil belajar kognitif peserta didik kelas VIII SMP Negeri 11 Jayapura. ini ditunjukan nilai sig. 0,313 lebih besar dari 0,05.

\section{SARAN}

Strategi pemecahan masalah dalam pembelajaran dapat dilakukan dengan berbagai metode untuk meningkatkan hasil belajar kognitif peserta didik.

\section{UCAPAN TERIMA KASIH}

Kepala Sekolah SMP Negeri 11 Jayapura yang telah memfasiltasi peneliti dalam penelitian ini hingga dapat terlaksana dengan baik

\section{DAFTAR PUSTAKA}

Dahyana. (2014). Penerapan Metode Demonstrasi Untuk Meningkatkan Hasil Belajar Peserta didik Dalam Pembelajaran IPA Terpadu. Jurnal Nalar Pendidikan, 2(2), 129-133;

Ernawati, I., Suharto, \& Kristina, A. I. (2015). Penerapan Strategi Pembelajaran Pemecahan Masalah Wankat Daan Oreovocz Dalam
Meningkatkan Hasil Belajar Peserta didik Pada Pokok Bahasan Sistem Persamaan Dan Tidak Persamaan Linear Satu Variabel Di Kelas VII SMP Moch. Sroedji Jember Tahun Ajaran 2013/2014. Jurnal Pendidikan Matematika, 4, 201212;

Hartono, B., \& Pratiwi, V. (2014). Penerapan Metode Eksperimen Untuk Meningkatkan Aktivitas Peserta didik Pada Mata Pelajaran IPA Kelas V Semester I SDN 4 Besuki Situbondo. 28-43;

Kholifudin, M. (2012). Pembelajaran Fisika dengan Inkuiri Terbimbing Melalui Metode Eksperimen dan Demonstrasi Ditinjau Dara Gaya Belajar Peserta didik. 147-152;

Komalasari, K. (2013). Pembelajaran Kontekstual Konsep dan Aplikasi. Bandung: Refika Aditama;

Linuhung, N. (2014). Pengaruh Strategi Pemecahan Masalah WankatOreovocz dan Pembelajaran Probing Terhadap Kemampuan Literasi Matematis Peserta didik SMP. Aksioma jurnal pendidikan matematika FKIP U.muhammadiyah metro, 4, 53-58;

Linuhung, N. (2015). Penerapan Strategi Pemecahan Masalah WankatOreovocz Dalam Peningkatkan Literasi Matematis Peserta didik SMP Ditinjau dari Pengetahuan Awal Matematis. 4, 53-58;

Mulyani. (2015). Penggunaan Metode Eksperimen Untuk Meningkatkan Hasil Belajar Tentang Rangkaian Listrik Seri Dan Paralel Pelajaran Ipa Pada Peserta didik Kelas Vi Sd Negeri 3 Karanggandu Kecamatan Watulimo Kabupaten Trenggalek. Jurnal Pendidikan Profesional, 4554 ; 
Jurnal Ilmu Pendidikan Indonesia 9 (2) : 68- $78 \mid 78$

Setiawan, I. G. (2008). Penerapan Pengajaran Kontekstual berbasis Masalah Untuk Meningkatkan Hasil Belajar Biologi Peserta didik Kelas X2 SMA Laboratorium Singaraja. Jurnal Penelitian dan Pengembangan Pendidikan, 42-59;

Subrata. (2016, April). Penerapan Metode Demonstrasi Pada Materi Asam Basa Garam Untuk Meningkatkan Aktivitas dan Hasil Belajar Peserta Didik. Jurnal Scientia Indonesia, 1, 37-34;
Supardi. (2015). Penilaian Autentik Pembelajaran Afektif, Kognitif dan Psikomotor. Jakarta: Rajawali Pers;

Supardianningsih, \& Nurani, D. (2014). Ilmu Pengetahuan Alam SMP/MTs Kelas VIII Semester 2. Klaten: PT. Intan Pariwara;

Wena, M. (2014). Strategi Pembelajaran Inovatif Kontemporer Suatu Tinjauan Konseptual Operasional. Jakarta: Bumi Aksara. 